Vitriak O., Candidate of Engineering, Associate Professor, Tkachenko L., Candidate of Engineering, Associate Professor Kyiv National University of Trade and Economics,

Kyiv, Ukraine

Google Scholar

https://scholar.google.com.ua/citations?user=hA7L74AAAAAJ\&hl=ru https://scholar.google.com.ua/citations?user=-SFxzpcAAAAJ\&hl=ru

\title{
THE USE OF RYE MALT EXTRACT IN DESSERTS TECHNOLOGY
}

In nature, there are no perfect foods with content of all the nutrients, that are needed to ensure a high level of human health. The human body needs a whole set of vitamins and minerals for normal functioning [1]. Today, the use of plant material is promising to create products, in particular desserts, with high biological value. In view of this, raw material for desserts were chosen such, due to its vitamin and mineral composition, positively affects the activity of human body systems, namely, the extract of rye malt and flower pollen.

Rye malt is rich in micro and macro elements, such as: Selenium, Potassium, Phosphorus, Manganese, Magnesium. Rye malt contains as well as vitamins: group a (Retinol), group b (Choline, Niacin), group e ( $\alpha$-Tocoferol) [2]. It is effectively used in diseases such as anemia, exhaustion, diabetes, and also helps to cleanse the body from harmful substances, slags and toxins.

Flower pollen contains valuable nutritious and biologically active substances, and many trace elements [3]. It consists of virtually all essential amino acids. Pollen contains vitamins, such as, Ascorbic acid, gpoup pp (Niacin), group k (Phylloquinone), group e ( $\alpha$-Tocoferol), group $\mathrm{d}$ (Ergocalciferol). Flower pollen strengthens the vascular walls, increases immunity, restores metabolic processes in the human body, increases hemoglobin.

Pectin has gelatin-like culinary properties similar to gelatin and it has a therapeutic and prophylactic effect on the body. That's why it was chosen as an ingredient in the desserts technology. Pectin is a natural gelling agent, that is contained in fruits and many types of vegetables and has the properties of removing toxins from the human body, lowering the level of cholesterol and sugar in the blood, and protecting it against radiation [4]. 
In order to remove from the rye malt the maximum amount of nutrients, the malt extract was prepared as follows: the weight of ground malted in the amount of $5 \mathrm{~g}$ was mixed with water at a ratio of 1:20 at a temperature of $40^{\circ} \mathrm{C}$, was stirred in a shaking apparatus for 15 minutes, kept in a water bath for $10 \mathrm{~min}$ and filtered. During the development of the «Apelsol» dessert technology we prepared model dessert compositions based on orange juice with flower pollen and apple pectin: replaced 10 to $30 \%$ water in experimental samples for extract of rye malt. The amount of pollen was from 0.1 to $3.0 \mathrm{~g}$ per $100 \mathrm{~g}$ of the finished product.

The organoleptic evaluation of the obtained products showed that the addition of rye malt extract enriches the dessert with pleasant flavoring properties. The best example was an experiment in which $20 \%$ of water was replaced by a malt extract. The addition of flower pollen improved the organoleptic characteristics of dessert due to the provision of floral aftertaste. For $100 \mathrm{~g}$ of product it is expedient to use $2 \mathrm{~g}$ of pollen.

The analysis of the chemical composition of the dessert «Apelsol» with the extract of rye malt and flower pollen is performed, that showed a significant change in the mineral and vitamin content of this dessert: increase in the content of Magnesium by $269 \%$, Potassium by $186 \%$, Iron by $750 \%$, Niacin by $250 \%$, Choline by $500 \%$, $\alpha$-Tocoferol by $200 \%$, Ascorbic acid by $319 \%$.

According to the research results, it can be concluded that the developed dessert «Apelsol» due to the addition of malt extract and flower pollen has an increased biological value, a greate number of micro and macro elements, mainly, Magnesium, Potassium and Iron, which contributes to the processes of hematopoiesis, respiration, oxidationreduction reactions. In addition, high level of vitamins groups $b$, c and e will improve the overall state of the human body.

\section{List of bibliographic references}

1. Kharchuvannya lyudyny i suchasne dovkillya: teoriya i praktyka : Monohrafiya / M.I. Peresichnyy, M.F. Kravchenko, O.M. Hryhorenko. Kyyiv: KNTEU, 2003. - $526 \mathrm{~s}$.

2. Informatsiyno-poshukovyy sayt [elektronnyy resurs] - rezhym dostupu: http://produkti/14139-solod-sklad-i-vlastivosti-vidi-i-korist-solodu.html

3. Informatsiyno-poshukovyy sayt [elektronnyy resurs] - rezhym dostupu: http://bioproduct.com.ua

4. Tekhnolohiya produktiv kharchuvannya funktsional'noho pryznachennya : monohrafiya / M.I. Peresichnyy, M.F. Kravchenko, D.V. Fedorova ta in. / Za red. M.I. Peresichnoho - K.: KNTEU,2008. -718 s. 